\title{
Critical problems associated with climate change: a systematic review and meta-analysis of Philippine fisheries research
}

\author{
Jen-Ming Liu ${ }^{1}$ • Elaine Quinatana Borazon ${ }^{2,3}$ (D) Kyrie Eleison Muñoz ${ }^{4}$ \\ Received: 8 February 2021 / Accepted: 24 July 2021 / Published online: 3 August 2021 \\ (C) The Author(s), under exclusive licence to Springer-Verlag GmbH Germany, part of Springer Nature 2021
}

\begin{abstract}
This paper proposes to analyze the scientific production on climate change and fisheries in the Philippine context. This research theme was chosen considering the continuous increase in scientific studies related to climate change and fisheries and will therefore help in directing researchers on future directions for research to aid in addressing critical issues in the Philippine fisheries. A total of 69 search articles were extracted using the set criteria, indexed in Web of Science, and Scopus, covering the period from 1960 to 2020 . After careful screening for eligibility, twenty-seven full-text articles were chosen for qualitative synthesis. Among the literature reviewed, research foci were categorized into four: impacts assessment (56\% or 15 studies) followed by management ( $22 \%$ or 6 studies), adaptation ( $15 \%$ or 4 studies), and perception ( $7 \%$ or 2 studies), and main themes were categorized into four: resource management (59\%), economy and livelihood (19\%), governance and stakeholder participation $(11 \%)$, and community marginalization (11\%). This review contributes to the literature by identifying research potentials and suggesting a prescriptive approach to Philippine fisheries and climate change studies.
\end{abstract}

Keywords PRISMA $\cdot$ Fisheries studies $\cdot$ Food security $\cdot$ Climate change $\cdot$ Philippines $\cdot$ Meta-analysis

\section{Introduction}

Climate change brought a more significant impact on the earth's ecosystem and in human communities (Wang et al. 2018). Countries in the Asia-Pacific region are comparatively susceptible than their Western counterparts in terms of periodic and stern disasters brought about by climate change (Seidler et al. 2018). In fact, climate change is seen to affect

Responsible Editor: Philippe Garrigues

Elaine Quinatana Borazon

elaineqborazon@mail.nsysu.edu.tw

1 Department of Fisheries Production and Management, College of Hydrosphere Science, National Kaohsiung University of Science and Technology, Kaohsiung, Taiwan

2 International Graduate Program of Education and Human Development, College of Social Sciences, National Sun Yat-sen University, Kaohsiung, Taiwan

3 PhD Program of Aquatic Science and Technology, College of Hydrosphere Science, National Kaohsiung University of Science and Technology, Kaohsiung, Taiwan

4 National Kaohsiung University of Hospitality and Tourism, Kaohsiung, Taiwan the fisheries sector of highly fish-dependent yet vulnerable countries such as the Philippines in terms of food production, security, and livelihood (Ding et al. 2017). The country's fishing sector is severely affected by the effects of climate change and is susceptible to hazards observed in the entire Southeast Asian (SEA) region (Gopal and Anbumozhi 2019). According to the same authors, the danger to food security is a mix of factors including climate and geography which are the warming up and rising of seawater, presence of waste and acid in the ocean, and the changes in rainfall and typhoons. This has been observed in the Philippines with the frequent and intensive weather extremes (Andriesse 2018). Accordingly, the study by Suh and Pomeroy (2020b) has revealed that the effect of climate change on Philippine marine capture fisheries is projected to result in a decrease in fisheries GDP by $9 \%$ and $18 \%$ under mitigation and extreme scenarios, respectively. These effects may also lead to a reduction in household income by $0.36 \%$ and $0.38 \%$ for urban and rural households, respectively. Global warming has also triggered coral reef bleaching, and the hotspot analysis done by Goreau and Hayes (2021) predicted mass coral bleaching in Indonesia, Japan, Taiwan, China, Guam, the entire Caribbean Sea, Great Barrier Reef, Palau, India, and the Philippines. A recent assessment of 206 fringing reefs in the 
country reveals that a third of their hard-coral cover is damaged, and none is in excellent condition (Licuanan 2020). At the global scale, climate change is likely to lead to a decrease in marine primary production (Food and Agriculture Organization 2018), specifically from coastal fisheries (Dey et al. 2016) and in South and Southeast Asia (Barange et al. 2014). According to Food and Agriculture Organization (2018), the total maximum catch potential at the world's exclusive economic zones (EEZs) is also projected to decrease by $2.6-12.1 \%$ by 2050 relative to the year 2000 . Similarly, fish processing and trading will be affected through challenges in processing techniques, flooding of roads, and reduced transport, including people migration and livelihood diversification.

Environmental pollution and degradation have also led to the loss of aquatic habitat, thereby affecting the fishing livelihood in the region (Pomeroy et al. 2016). Land-based emissions, such as atmospheric pollutants due to increasing urbanization, human settlements, and tourism, are major contributors to marine pollution (Williams 1996), and these have economic repercussions. Marine litter, for example, is shown to have an annual economic cost of $\$ 3300-\$ 33,000$ per ton of marine plastic (Beaumont et al. 2019). Moreover, according to Bergland et al. (2019), pollution density is likely to negatively affect fishery due to a decrease in biological growth potential in the ocean leading to an impact on inland fish biomass (Allan et al. 2005). Additionally, global warming (as may be affected by environmental pollution) negatively affects coral reef ecosystems (Goreau and Hayes 2021). As a response, there has been a global consensus to provide solutions on the impacts and threats of climate change in the fisheries sector by developing policies and programs on mitigation and adaptation strategies emphasizing on vulnerability, sustainability, and resilience (Miao 2018). The views of Blasiak et al. (2017) corroborate this claim by pointing out that impacts on fishing brought about by climate change can be reduced by minimizing vulnerability. In the same light, the sustainability of fishery supply for consumption remains a threat alongside climate change (Tran et al. 2017). This is also an issue for fishing productivity due to overfishing and overexploitation (McIntyre et al. 2016). As such, programs such as climate change resiliency, on the other hand, are seen as key in assessing and acting upon the inherent impacts of climate change (Blanchard et al. 2017).

The Philippines, as an archipelagic country, has relied on fisheries for food security and economic gains (Palomares and Pauly 2014; Santos et al. 2011). However, the advent of climate change-induced effects has left the Philippines as one of the most exposed to these consequences (Badjeck et al. 2010; Food and Agriculture Organization of the United Nations 2016) which is seen to impact food security and the entire economy of the country (Suh and Pomeroy 2020a). With this, Macusi et al. (2015) argue that the consequences of climate change be addressed. In response to the importance of the fisheries sector and the growing interest in examining the impacts associated with climate change worldwide, the authors deem it imperative to appraise the current body of knowledge because of the scarce literature on this discourse. Although the inquiry on the impacts of climate change on the fisheries sector has already been instigated by some scholars (Geronimo 2018; Santos et al. 2011), this study is poised to address the research aim of mapping out what has been done in and what can be explored further by investigating and synthesizing existing literature on the subject contextualized in the Philippine setting. By doing so, this paper contributes by answering the question "How does the current literature interrogate the phenomenon of climate change-induced issues in Philippine fisheries?" By locating the extent of the body of knowledge, this study offers which direction scholars can take in the future as well as recommendations for the private and public sector in addressing critical issues in Philippine fisheries.

\section{Methodology}

This paper applies the Preferred Reporting Items for Systematic Reviews and Meta-Analyses (PRISMA) to carry out the systematic literature review employed in this study, as represented in Figure 1. This approach is a published guideline that facilitates a process-orientated flow for researchers to extensively evaluate and engage reviewed resources (Moher et al. 2009) and has also been utilized by several researchers (Gong et al. 2021; Kamaraj et al. 2021; Li et al. 2020; Sharma and Oremus 2018). The PRISMA approach requires four stages: (1) identification; (2) screening; (3) eligibility assessment; and (4) inclusion. Records are first identified through database searching followed by removal of duplicates or those articles that appear more than once. Screening then follows, which means removing articles that are not relevant to the topic of interest or the research question. Eligibility assessment entails evaluating the remaining articles if these are related to the topic of interest by browsing through the abstract and or content of the articles. The inclusion step is getting the difference between the number of articles excluded and the number of articles that passed the eligibility assessment (Page et al. 2021). The researchers deem this as the suited approach in order to produce a strong, transparent, and wide review of related literature that can provide a compelling response to the set research objectives (Mohamed Shaffril et al. 2019). A synthesis of previous studies is an important task to advance knowledge (Lima and Bonetti 2020). This paper narrowed down with the following terms for the search: "climate change" and "fish" and "Philippines" as its title, keywords, and abstract. 


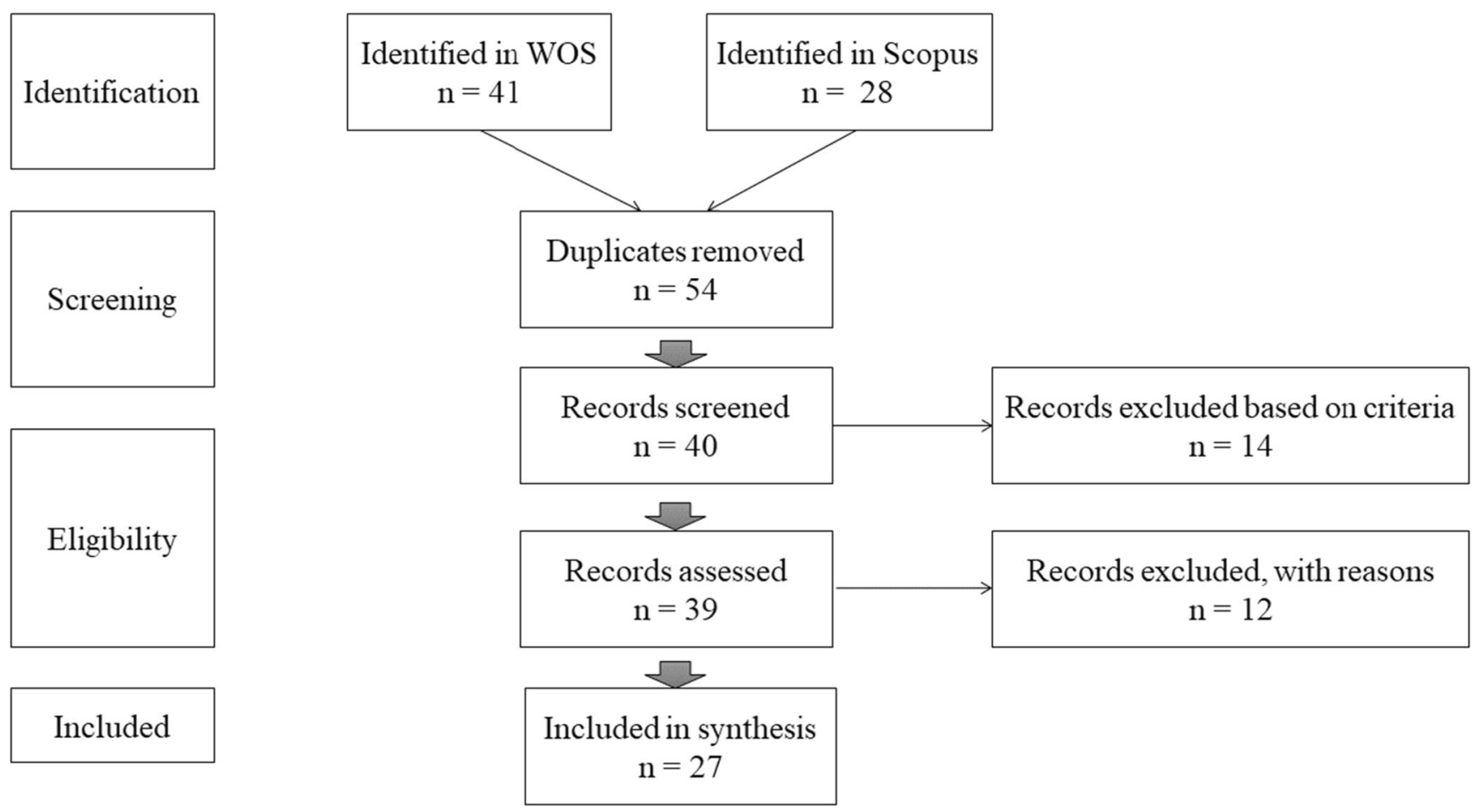

Fig. 1. Flow diagram of the study (adapted from Moher et al. (2009))

The review protocol identified Web of Science (https:// apps.webofknowledge.com/) and Scopus (https://www. scopus.com/sources.uri?zone $=$ TopNavBar\&origin $=$ searchbasic) as the database where the literature to be reviewed will be drawn. These two databases were chosen because of the comprehensiveness and quality included in its portfolio with over 1,400 combined count of journals related to environmental studies. This is in line with common practice in systematic literature reviews which employ two to three databases (Yang et al. 2017). For the purpose of this study, only full-text English peer-reviewed journal articles and reviews published from 1960 to 2020 were considered. The authors are interested to see what fishery-climate change-related researches in the Philippines have been done and the emergent themes in the last 60 years. As of 12 December 2020, a total of 69 (41 from WoS and 28 from Scopus) search articles were extracted using the set criteria. Duplicate titles were excluded, while the rest screened further to discard entries not satisfying the criteria set above. The remaining titles were then assessed for eligibility by reviewing the title, abstract, and content. The search concluded with 27 full-text articles eligible for the qualitative synthesis.

A summary of findings was described by reporting the year of publication, journal publication, and methodology used. To identify the research streams and core topics covered and their co-occurrences and get an overview of the evolution of publication, network analysis was used with the aid of VOSViewer (van Eck and Waltman 2010). Thematic analysis was used to develop themes, understand concepts, and give meaning to the ideas reflected on each reviewed paper's main foci, findings, and conclusions.

\section{Results and discussions}

Reviewed literature on critical problems in the Philippine fisheries sector associated with climate change has been published more recently with 2020 comprising 19\% and 2016 comprising 15\% (see Table 1). This reflects two points on the impacts of climate change on the Philippine fisheries: (1) discussion is gaining popularity in the field of research, and 2) literature on this context remains scant and under-researched.

From the 27 papers reviewed, $74 \%$ or 20 studies have used quantitative methodology, while $15 \%$ or 4 studies used qualitative method, while $11 \%$ or 3 studies utilized mixed methods. This shows that scholars prefer using a positivist paradigm with some inclination to triangulation in understanding critical issues in the fisheries sector associated with climate change. Table 2 shows the literature profile by methodology. Qualitative research "involves studying the meaning of people's lives as experienced under real-world conditions" (Yin 2016). This includes case studies, ethnography, phenomenology, grounded theory, and discourse analysis, among others. The quantitative methodology focuses on measuring amount or quantity (Kothari 2004), while a mixed methodology refers to a combination of both quantitative and qualitative methods (Creswell and Plano Clark 2017). 
Table 1. Literature profile by year of publication

\begin{tabular}{|c|c|c|c|}
\hline Year & $\begin{array}{l}\text { No. of } \\
\text { Studies }\end{array}$ & $\%$ & Journal name/publisher \\
\hline 2020 & 5 & 19 & Journals: \\
\hline 2019 & 3 & 11 & \multirow{8}{*}{$\begin{array}{l}\text { Coral Reefs; Asia Pacific Viewpoint, Regional Environmental Change, } \\
\text { Aquaculture, Freshwater Biology, Global Ecology and Biogeography, Marine } \\
\text { Pollution Bulletin, Conservation Letters, Ocean \& Coastal Management, PLoS } \\
\text { ONE, Fish and Fisheries, Fisheries Research, Geo: Geography and } \\
\text { Environment, Fish and Fisheries, Ocean \& Coastal Management, } \\
\text { Hydrobiologia, Fisheries Research, Environmental Modelling \& Software, } \\
\text { Marine Policy, Ocean \& Coastal Management, Economic Analysis and Policy, } \\
\text { ICES Journal of Marine Science, Ecological Applications, Coastal } \\
\text { Management Restoration Ecology, Frontiers in Marine Science, Harmful Algae }\end{array}$} \\
\hline 2018 & 3 & 11 & \\
\hline 2017 & 1 & 4 & \\
\hline 2016 & 4 & 15 & \\
\hline 2015 & 3 & 11 & \\
\hline 2014 & 2 & 7 & \\
\hline 2013 & 3 & 11 & \\
\hline 2012 & 0 & 0 & \\
\hline 2011 & 1 & 4 & \multirow{3}{*}{$\begin{array}{l}\text { Publishers: } \\
\text { Elsevier, Wiley, Springerlink, Oxford University Press, Frontiers Media S. A, } \\
\text { PLOS, Taylor \& Francis }\end{array}$} \\
\hline 2010 & 2 & 7 & \\
\hline Total & 27 & 100 & \\
\hline
\end{tabular}

Figure 2 shows the most frequently used terms in the titles, keywords, and abstracts of studies being reviewed. Three loosely connected clusters are evident, colored in blue, green, and red. Red clusters contained terms related to biomass, marine protected area, and coral cover, while the green cluster contained terms such as community, livelihood, impact, and small-scale fishery. The blue cluster contained terms such as management, reef system, and fishing. This method reveals the frequently co-occurring terms to cluster together and can represent research areas presented in the body text.

Among the literature reviewed using thematic analysis, this paper categorized reviewed studies in four, based on title, keywords, careful analysis of the paper, and frequently used terms: impacts assessment (56\% or 15 studies) followed by management ( $22 \%$ or 6 studies), adaptation (15\% or 4 studies), and perception (7\% or 2 studies), as shown in Table 3. These categories were drawn from the thorough analysis of each research's subjects of investigation.

Impacts assessment was a recurring theme. Blanchard et al. (2017) point out the importance of understanding the scope and extent of climate-change-induced impacts. Similarly, reviewed studies have ventured in this direction to appraise the vulnerability of sector-based fishing (Jacinto et al. 2015) and examine how climate change has affected the macroeconomy (Suh and Pomeroy 2020a). Both studies have

Table 2. Literature profile by methodology

\begin{tabular}{lll}
\hline Methodology & No. of studies & $\%$ \\
\hline Quantitative & 20 & $74.0 \%$ \\
Qualitative & 4 & $15.0 \%$ \\
Mixed methodology & 3 & $11 \%$ \\
Total & 27 & \\
\hline
\end{tabular}

contributed by proposing impact-specific models to forecast and prepare beforehand.

We can argue that the existing body of knowledge has attempted to address the need to propose adaptation strategies and management of resources on climate change which Lindegren and Brander (2018) coin as still pending. According to them, adaptation should not be reactive and divorced from communities. Adaptation has likewise gained ground in other literature. In fact, Miao (2018) posits that strategy developments such as this enable progress in the understanding of mitigating risks and vulnerabilities associated with climate change. Reviewed literature has discussed climate change adaption policies in the context of the gender dimension (Graziano et al. 2018), at the community level (Andriesse et al. 2020; Macusi et al. 2020), and post-disaster recovery (Drury O'Neill et al. 2019). These papers emphasized the need for strategic approaches laden on specific vulnerabilities in order to address the critical issues associated with climate change.

Lastly, researchers have delved into perception studies. As Mulyasari et al. (2018) argue, the impressions and judgments of fisher folks are vital in the discourse mitigating climate change issues because such perceptions are shaped by experiences and time spent in the conduct of fishing. Reviewed literature showed similar adherence to this argument and expanded to identify the perceptions of local stakeholders (Quevedo et al. 2020) and high school students (Lagbas and Habito 2016). Such studies have carried on with the notion that the community members' knowledge is essential in improving sustainability towards current fishing practices.

On the other hand, the main themes were derived from the reviewed literature' research foci. These include resource management (59\%), economy and livelihood (19\%), governance and stakeholder participation (11\%), and community marginalization (11\%), as reflected in Table 4. Fisheries 


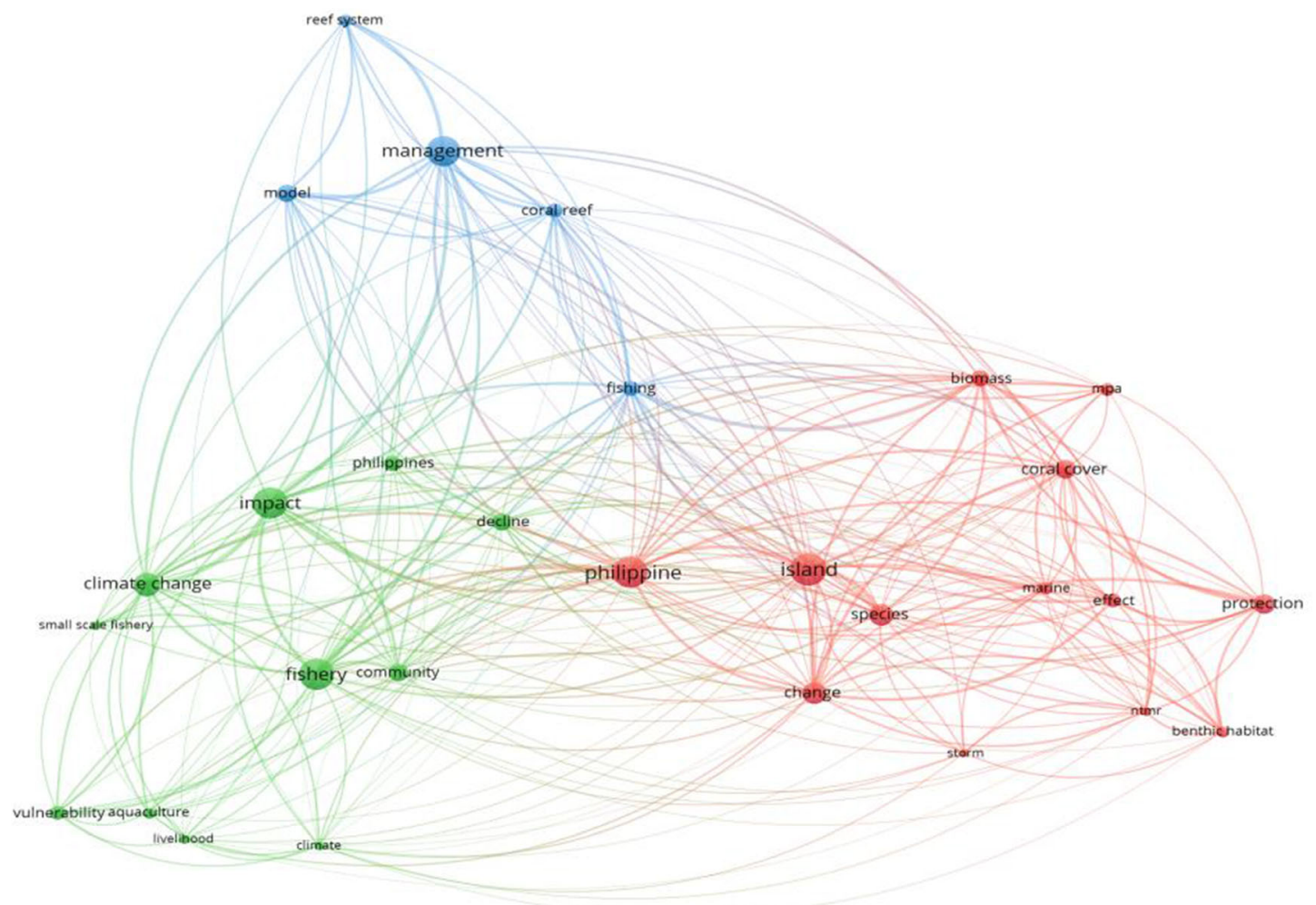

s vosviewer

Figure 2. Occurrence network map of keywords, titles, and abstracts of studies on climate change and fisheries in the Philippines

remain a means for food security and economic driver in the Philippines (Ding et al. 2017). According to Suh and Pomeroy (2020a), climate change will deal long-term economic impacts on the Philippines and cause a drop between 9 and $18 \%$ in fisheries GDP by 2060 . Climate change has likewise threatened the fisheries sector with environmental implications (Johnson and Harrison 2015; Yamaguchi and Sai 2015) which eventually led to certain impacts on livelihood (Mulyasari et al. 2018). As Macusi et al. (2020), Filipino fisher folks in Eastern Mindanao are vulnerable because several factors, including environmental changes, have influenced their livelihood in fishing. Typhoons, which are getting stronger, more frequent, larger in scale, and longer in duration, cause severe damage to coral reef communities (Abesamis et al. 2018; Anticamara and Go 2017). Climate change may also lead to substantial damage of insular habitats due to sealevel rise (Bellard et al. 2014). Hence, alternative livelihoods to offset such vulnerabilities should be addressed by onward strategies (Jacinto et al. 2015).

The role of government and different stakeholders has enhanced support for fisheries in adapting to climate change (Miao 2018). In fact, adapting to climate change by

Table 3. Categories of literature

\begin{tabular}{|c|c|c|c|}
\hline Theme & $\begin{array}{l}\text { No. of } \\
\text { studies }\end{array}$ & $\%$ & List of articles (by authors) \\
\hline $\begin{array}{l}\text { Impacts } \\
\text { assess- } \\
\text { ment }\end{array}$ & 15 & $56 \%$ & $\begin{array}{l}\text { Abesamis et al. (2018), Anticamara and Go (2017), Aubin et al. (2015), } \\
\text { Bannister et al. (2019), Bellard et al. (2014), Legaspi et al. (2015), } \\
\text { Macusi et al. (2020), Magdaong et al. (2014), Mamauag et al. (2013), } \\
\text { Muallil et al. (2014), Nong (2019), Russ et al. (2020), Shaish et al. } \\
\text { (2010), Suh and Pomeroy (2020a), Yñiguez et al. (2020) }\end{array}$ \\
\hline Management & 6 & $22 \%$ & $\begin{array}{l}\text { Duncan et al. (2016), Fox et al. (2012), Gurney et al. (2013), } \\
\text { Melbourne-Thomas et al. (2011), Muallil et al. (2019), Servonnat et al. } \\
\text { (2019) }\end{array}$ \\
\hline Adaptation & 4 & $15 \%$ & $\begin{array}{l}\text { Andriesse et al. (2020), Graziano et al. (2018), Handisyde et al. (2017), } \\
\text { Jacinto et al. (2015) }\end{array}$ \\
\hline Perceptions & 2 & $7 \%$ & Locke et al. (2017), Pauly (2016) \\
\hline Total & 27 & & \\
\hline
\end{tabular}


Table 4. Main themes

\begin{tabular}{lll}
\hline Themes & No. of studies & $\%$ \\
\hline Resource management & 16 & $59 \%$ \\
Economy and livelihood & 5 & $19 \%$ \\
Governance and stakeholder participation & 3 & $11 \%$ \\
Community marginalization & 3 & $11 \%$ \\
Total & 27 & \\
\hline
\end{tabular}

integrating governance (Rizal and Anna 2018) and the other community actors is essential in alleviating its impacts (Macusi et al. 2015). Reviewed studies have explored on this thought by investigating current management practices (Quevedo et al. 2020) and sustainable thinking (Lagbas and Dl. Habito, 2016). On the other hand, formal governance and structural strategies were examined by Drury O'Neill et al. (2019). Based on their study, systematic power relations remain at the forefront of Philippine governance in fishing. This corroborates with the position of various scholars (de Leon and Pittock 2017; Heenan et al. 2015) which states that governance remains a barrier and that decision-making should be restructured by employing integration and cooperation among all concerned. This theme is closely linked to community marginalization, which emerged as the last finding. From the papers reviewed, this theme pertains to how the issues in fisheries associated with climate change have also touched the belittling of women (Graziano et al. 2018) and small-scale fishers (Andriesse et al. 2020).

\section{Conclusions and recommendations}

A systematic literature review was facilitated in order to determine how the current body of knowledge interrogates the critical impacts on the fisheries sector associated with climate change as contextualized in the Philippine setting. Using Web of Science and Scopus as databases, this paper has analyzed and synthesized 27 pieces of literature to answer the research aim. Based on this, the researchers have identified the trend in publication years as well as the favored methodology. From 2010 to 2020, studies on climate change in relation to fisheries published in WoS and Scopus are few, averaging approximately 3 published studies per year. The year 2020 has seen an increase, with 5 papers as of writing. For the twenty-seven papers identified and reviewed, $74 \%$ employed quantitative methods, $15 \%$ pursued qualitative, while the rest conducted mixed methods. This shows that scholars prefer using a positivist paradigm with some inclination to triangulation in understanding critical issues in the fisheries sector associated with climate change.
Likewise, the findings of this paper present four categories and four main themes which point out what has been done in recent years. The thematic analysis on these papers' categories revolved around resource management, adaptation, impacts assessments, and perceptions. These studies revolve around strategies on how to manage fishery resources, build resilience, and improve current practices and policies concerning fishing and climate change. Second, measurement tools and models were designed and utilized in order to determine the extent of vulnerabilities and negative outcomes associated with climate change in the fisheries sector. Third, papers have also explored on understanding the attitudes and beliefs of various actors on their perceptions on climate change in the context of fisheries. Subsequently, themes such as resource management, economy and livelihood, governance and stakeholder participation, and community marginalization have also emerged from the research foci of the papers reviewed. For one, fisheries remain as an economic and income driver for the entire Philippines. Climate change is seen as a factor that can highly influence both economy and livelihood of all actors. Next, strategies on fishing from the perspective of all stakeholders were examined by scholars. Reviewed research showed that integration and cooperation are vital in sustainable fishing amid climate change. Lastly, specific groups remain vulnerable in fishing. This points out the need to further investigate the influences of marginalized groups and their role in fisheries.

The contribution of this paper is twofold. For one, the findings call on for both the public and private sector by responding to management strategies and policy changes which address the gaps mentioned in each main theme. The economic sphere of fishing with respect to livelihood generation should be anchored on the ability of the fisheries sector to cope with environmental changes. As such, cooperation and integration towards decision-making are vital as pointed out in the second theme. Capacity building and human capital investment can hence ensure that no specific group gets left behind and marginalized in the development of fishing. There should be recognition of the role of women in the fishery sector and demands for equal opportunity. Adaptive strategies to overcome fisher folk marginalization, spatial planning, and curbing of illegal and unsustainable fishing are also necessary to lessen the impact of climate change on vulnerable communities. Second, the authors direct future research on impacts assessments and perception studies by diversifying the samples to cover under-researched areas such as needs assessment of fishermen, under-represented groups such as indigenous fisher folks, the role of women, and underinvestigated geographic locations such as the Visayas. Spatial management research anchored on climate change for small-scale fisheries might offer recommendations for adaptation strategies. Also, researches on the impact of climate change laws (i.e., Climate Change Act of 2009) and policies 
or other forms of interventions might aid government agencies to review and revise their existing policies. Another direction for research might be related to longline fishing and its ecological impact (Griffiths et al. 2010) and stock assessment models for fisheries management (Tanaka 2019). Moreover, researches on climate change should be carried out within the multifaceted context of Philippine fisheries, taking into consideration scientific management, culture, respect for indigenous communities, territorial disputes, and sustainable fishery operations. Not only will this contribute to further the inquiry on critical problems associated with climate change but also improve the limited literature available in the context of the Philippines. Furthermore, succeeding review papers can replicate this study by examining what has been done and what can be done in other neighboring Asian countries such as Indonesia and Vietnam who likewise rely on fisheries and are impacted by climate change. The feasibility of conducting further studies, however, may be influenced by the COVID19 situation, government policies, security, and accessibility of the fishery areas in the Philippines.

Author contribution Jen-Ming Liu-Data collection, study design, data analysis, manuscript writing

Elaine Q. Borazon-Study design, data collection, data analysis, manuscript writing

Kyrie Eleison Muñoz-Manuscript writing, data analysis, data collection

Data Availability Not applicable

\section{Declarations}

Ethical approval Not applicable as no human participants are involved.

Consent to participate Not applicable as no human participants are involved.

Consent to publish Not applicable

Competing interests The authors declare no competing interests.

\section{References}

Abesamis RA, Langlois T, Birt M, Thillainath E, Bucol AA, Arceo HO, Russ GR (2018) Benthic habitat and fish assemblage structure from shallow to mesophotic depths in a storm-impacted marine protected area. Coral Reefs 37(1):81-97

Allan JD, Abell R, Hogan Z, Revenga C, Taylor B, Welcomme R, Winemiller K (2005) Overfishing of Inland Waters. Bioscience 55(12):1041-1051

Andriesse E (2018) Persistent fishing amidst depletion environmental and socio-economic vulnerability in Iloilo Province, the Philippines. Ocean Coast Manag 157:130-137

Andriesse E, Kittitornkool J, Saguin K, Kongkaew C (2020) Can fishing communities escape marginalisation? Comparing overfishing, environmental pressures and adaptation in Thailand and the Philippines. Asia Pacific Viewpoint 62(3):72-85

Anticamara JA, Go KTB (2017) Impacts of super-typhoon Yolanda on Philippine reefs and communities. Reg Environ Chang 17(3):703713

Aubin J, Baruthio A, Mungkung R, Lazard J (2015) Environmental performance of brackish water polyculture system from a life cycle perspective: a Filipino case study. Aquaculture 435:217-227

Badjeck M-C, Allison EH, Halls AS, Dulvy NK (2010) Impacts of climate variability and change on fishery-based livelihoods. Mar Policy 34(3):375-383

Bannister W, McGowan S, Santos-Borja AC, Quak J, Fong LS, Mendoza M, Papa RDS, Taylor D (2019) Potential anthropogenic regime shifts in three freshwater lakes in Tropical East Asia. Freshw Biol 64(4):708-722

Barange M, Merino G, Blanchard JL, Scholtens J, Harle J, Allison EH, Allen JI, Holt J, Jennings S (2014) Impacts of climate change on marine ecosystem production in societies dependent on fisheries. Nat Clim Chang 4(3):211-216

Beaumont NJ, Aanesen M, Austen MC, Börger T, Clark JR, Cole M, Hooper T, Lindeque PK, Pascoe C, Wyles KJ (2019) Global ecological social and economic impacts of marine plastic. Mar Pollut Bull 142:189-195

Bellard C, Leclerc C, Courchamp F (2014) Impact of sea level rise on the 10 insular biodiversity hotspots. Glob Ecol Biogeogr 23(2):203-212

Bergland H, Pedersen PA, Wyller J (2019) Accumulated marine pollution and fishery dynamics. Ecol Complex 38:56-74

Blanchard JL, Watson RA, Fulton EA, Cottrell RS, Nash KL, BryndumBuchholz A, Büchner M, Carozza DA, Cheung WWL, Elliott J, Davidson LNK, Dulvy NK, Dunne JP, Eddy TD, Galbraith E, Lotze HK, Maury O, Müller C, Tittensor DP, Jennings S (2017) Linked sustainability challenges and trade-offs among fisheries, aquaculture and agriculture. Nature Ecology \& Evolution 1(9): $1240-1249$

Blasiak R, Spijkers J, Tokunaga K, Pittman J, Yagi N, Österblom H (2017) Climate change and marine fisheries: least developed countries top global index of vulnerability. PLoS ONE 12(6):e0179632. https://doi.org/10.1371/journal.pone.0179632

Creswell JW, Plano Clark VL (2017) Designing and Conducting mixed methods research. University of Cincinnati, OH, USA

de Leon EG, Pittock J (2017) Integrating climate change adaptation and climate-related disaster risk-reduction policy in developing countries: a case study in the Philippines. Clim Dev 9(5):471-478

Dey MM, Rosegrant MW, Gosh K, Chen OL, Valmonte-Santos R (2016) Analysis of the economic impact of climate change and climate change adaptation strategies for fisheries sector in Pacific coral triangle countries: model estimation strategy, and baseline results. Mar Policy 67:156-163

Ding Q, Chen X, Hilborn R, Chen Y (2017) Vulnerability to impacts of climate change on marine fisheries and food security. Mar Policy 83: $55-61$

Drury O'Neill E, Crona B, Ferrer AJ, Pomeroy R (2019) From typhoons to traders: the role of patron-client relations in mediating fishery responses to natural disasters. Environ Res Lett 14:045015

Duncan C, Primavera JH, Pettorelli N, Thompson JR, Loma RJA, Koldewey HJ (2016) Rehabilitating mangrove ecosystem services: a case study on the relative benefits of abandoned pond reversion from Panay Island, Philippines. Mar Pollut Bull 109(2):772-782

Food and Agriculture Organization (2018) Impacts of climate change on fisheries and aquaculture. Rome, Food and Agriculture Organization

Food and Agriculture Organization of the United Nations (2016) The state of world fisheries and aquaculture 2016, Rome

Fox HE, Mascia MB, Basurto X, Costa A, Glew L, Heinemann D, Karrer LB, Lester SE, Lombana AV, Pomeroy RS, Recchia CA, Roberts CM, Sanchirico JN, Pet-Soede L, White AT (2012) Reexamining 
the science of marine protected areas: linking knowledge to action. Conserv Lett 5(1):1-10

Geronimo RC (2018) Projected climate change impacts on Philippine marine fish distributions. Department of Agriculture - Bureau of Fisheries and Aquatic Resources, Philippines

Gong X, Sui L, Morton J, Brennan MA, Brennan CS (2021) Investigation of nutritional and functional effects of rice bran protein hydrolysates by using Preferred Reporting Items for Systematic Reviews and Meta-Analysis (PRISMA) guidelines: a review. Trends Food Sci Technol 110:798-811

Gopal T, Anbumozhi V (2019) Effects of disasters and climate change on fisheries sectors and implications for ASEAN food security. In: Anbumozhi V, Breiling M, Reddy V (eds) Towards a Resilient ASEAN Disasters, Climate Change, and Food Security: Supporting ASEAN Resilience, vol 1. Economic Research Institute for ASEAN and East Asia, Jakarta, Indonesia, pp 161-188

Goreau TJF, Hayes RL (2021) Global warming triggers coral reef bleaching tipping point. Ambio 50(6):1137-1140

Graziano K, Pollnac R, Christie P (2018) Wading past assumptions: gender dimensions of climate change adaptation in coastal communities of the Philippines. Ocean Coast Manag 162:24-33

Griffiths SP, Young JW, Lansdell MJ, Campbell RA, Hampton J, Hoyle SD, Langley A, Bromhead D, Hinton MG (2010) Ecological effects of longline fishing and climate change on the pelagic ecosystem off eastern Australia. Rev Fish Biol Fish 20(2):239-272

Gurney GG, Melbourne-Thomas J, Geronimo RC, Alino PM, Johnson CR (2013) Modelling coral reef futures to inform management: can reducing local-scale stressors conserve reefs under climate change? PLoS One 8(11):17

Handisyde N, Telfer TC, Ross LG (2017) Vulnerability of aquaculturerelated livelihoods to changing climate at the global scale. Fish Fish 18(3):466-488

Heenan A, Pomeroy R, Bell J, Munday PL, Cheung W, Logan C, Brainard R, Yang Amri A, Aliño P, Armada N, David L, RiveraGuieb R, Green S, Jompa J, Leonardo T, Mamauag S, Parker B, Shackeroff J, Yasin Z (2015) A climate-informed ecosystem approach to fisheries management. Mar Policy 57:182-192

Jacinto MR, Songcuan AJG, Yip GV, Santos MD (2015) Development and application of the fisheries vulnerability assessment tool (Fish Vool) to tuna and sardine sectors in the Philippines. Fish Res 161: 174-181

Johnson A, Harrison M (2015) The increasing problem of nutrient runoff on the coast: as development increases along coastlines worldwide, water quality-and everything that depends on it-degrades. Am Sci 103:98+

Kamaraj A, Kyriacou H, Seah KTM, Khan WS (2021) Use of human induced pluripotent stem cells for cartilage regeneration in vitro and within chondral defect models of knee joint cartilage in vivo: a Preferred Reporting Items for Systematic Reviews and MetaAnalyses systematic literature review. Cytotherapy. 23:647-661

Kothari CR (2004) Research metholodgy. New Age International Publishers, India

Lagbas AJ, Habito DC (2016) Ecosystem services of coastal and fisheries resources: Perspectives of high school students in Municipality of Panukulan, Polillo Island, Quezon, Philippines. Journal of Marine and Island Cultures 5(2):145-158

Legaspi K, Lau AYA, Jordan P, Mackay A, McGowan S, McGlynn G, Baldia S, Papa RD, Taylor D (2015) Establishing the impacts of freshwater aquaculture in tropical Asia: the potential role of palaeolimnology. Geo: Geography and Environment 2(2):148-163

Li T, Hua F, Dan S, Zhong Y, Levey C, Song Y (2020) Reporting quality of systematic review abstracts in operative dentistry: an assessment using the PRISMA for Abstracts guidelines. J Dent 102:103471

Licuanan WY (2020) Current management, conservation, and research imperatives for Philippine coral reefs. Philipp J Sci 149(3)
Lima CO, Bonetti J (2020) Bibliometric analysis of the scientific production on coastal communities' social vulnerability to climate change and to the impact of extreme events. Nat Hazards 102(3):1589-1610

Lindegren M, Brander K (2018) Adapting fisheries and their management to climate change: a review of concepts, tools, frameworks, and current progress toward implementation. Reviews in Fisheries Science \& Aquaculture 26(3):400-415

Locke C, Muljono P, McDougall C, Morgan M (2017) Innovation and gendered negotiations: Insights from six small-scale fishing communities. Fish Fish 18(5):943-957

Macusi E, Abreo NA, Abreo S, Cuenca G, Ranara CT, Ranara B, Cardona L, Andam M, Guanzon G, Katikiro R, Deepananda KHM, Macusi E, Cuenca N, Ranara G, Cardona C, Andam L, Guanzon M, Katikiro G, Ashoka K (2015) The potential impacts of climate change on freshwater fish fish culture and fishing communities. Journal of Nature Studies 14:14-31

Macusi ED, Macusi ES, Jimenez LA, Catam-isan JP (2020) Climate change vulnerability and perceived impacts on small-scale fisheries in eastern Mindanao. Ocean Coast Manag 189:105143

Magdaong ET, Fujii M, Yamano H, Licuanan WY, Maypa A, Campos WL, Alcala AC, White AT, Apistar D, Martinez R (2014) Longterm change in coral cover and the effectiveness of marine protected areas in the Philippines: a meta-analysis. Hydrobiologia 733(1):517

Mamauag SS, Alino PM, Martinez RJS, Muallil RN, Doctor MVA, Dizon EC, Geronimo RC, Panga FM, Cabral RB (2013) A framework for vulnerability assessment of coastal fisheries ecosystems to climate change-tool for understanding resilience of fisheries (VATURF). Fish Res 147:381-393

McIntyre PB, Reidy Liermann CA, Revenga C (2016) Linking freshwater fishery management to global food security and biodiversity conservation. Proc Natl Acad Sci U S A 113(45):12880-12885

Melbourne-Thomas J, Johnson CR, Alino PM, Geronimo RC, Villanoy CL, Gurney GG (2011) A multi-scale biophysical model to inform regional management of coral reefs in the western Philippines and South China Sea. Environ Model Softw 26(1):66-82

Miao W (2018) FAO/APFIC 1 regional consultation on building climate resilient fisheries and aquaculture in asia-pacific. FAO Aquaculture Newsletter 58:15-16

Mohamed Shaffril HA, Samah AA, Samsuddin SF, Ali Z (2019) Mirrormirror on the wall what climate change adaptation strategies are practiced by the Asian's fishermen of all? J Clean Prod 232:104 117

Moher D, Liberati A, Tetzlaff J, Altman DG (2009) Preferred reporting items for systematic reviews and meta-analyses: the PRISMA statement 339:b2535

Muallil RN, Mamauag SS, Cababaro JT, Arceo HO, Aliño PM (2014) Catch trends in Philippine small-scale fisheries over the last five decades: the fishers' perspectives. Mar Policy 47:110-117

Muallil RN, Deocadez MR, Martinez RJS, Campos WL, Mamauag SS, Nanola CL, Alino PM (2019) Effectiveness of small locallymanaged marine protected areas for coral reef fisheries management in the Philippines. Ocean Coast Manag 179:7

Mulyasari G, Irham I, Waluyati L, Suryantini A (2018) Perceptions and local adaptation strategies to climate change of marine capture fishermen in Bengkulu Province, Indonesia. IOP Conference Series: Earth and Environmental Science 200:012037

Nong D (2019) Potential economic impacts of global wild catch fishery decline in Southeast Asia and South America. Economic Analysis and Policy 62:213-226

Page MJ, Moher D, Bossuyt PM, Boutron I, Hoffmann TC, Mulrow CD, Shamseer L, Tetzlaff JM, Akl EA, Brennan SE, Chou R, Glanville J, Grimshaw JM, Hróbjartsson A, Lalu MM, Li T, Loder EW, MayoWilson E, McDonald S, McGuinness LA, Stewart LA, Thomas J, Tricco AC, Welch VA, Whiting P, McKenzie JE (2021) PRISMA 
2020 explanation and elaboration: updated guidance and exemplars for reporting systematic reviews. BMJ 372:n160

Palomares ML, Pauly D (2014) Philippine marine fisheries catches : a bottom-up reconstruction, 1950 to 2010. Fish Cent Res Rep 22(1)

Pauly D (2016) Having to science the hell out of it. ICES J Mar Sci 73(9): 2156-2166

Pomeroy R, Parks J, Courtney K, Mattich N (2016) Improving marine fisheries management in Southeast Asia: Results of a regional fisheries stakeholder analysis. Mar Policy 65:20-29

Quevedo JMD, Uchiyama Y, Kohsaka R (2020) Perceptions of the seagrass ecosystems for the local communities of Eastern Samar, Philippines: Preliminary results and prospects of blue carbon services. Ocean Coast Manag 191:105181

Rizal A, Anna Z (2018) Climate change and its possible food security implications toward Indonesian marine and fisheries. World News of Natural Sciences 22:119-128

Russ GR, Rizzari JR, Abesamis RA, Alcala AC (2020) Coral cover a stronger driver of reef fish trophic biomass than fishing. Ecol Appl 31(1):e02224

Santos M, Dickson JO, Velasco PEL (2011) Mitigating the impacts of climate change: Philippine fisheries in focus. Fish People 9:103-112

Seidler R, Dietrich K, Schweizer S, Bawa KS, Chopde S, Zaman F, Sharma A, Bhattacharya S, Devkota LP, Khaling S (2018) Progress on integrating climate change adaptation and disaster risk reduction for sustainable development pathways in South Asia: evidence from six research projects. International Journal of Disaster Risk Reduction 31:92-101

Servonnat M, Kaye R, Siringan FP, Munar J, Yap HT (2019) Imperatives for conservation in a threatened center of biodiversity. Coast Manag 47(5):453-472

Shaish L, Levy G, Katzir G, Rinkevich B (2010) Coral reef restoration (Bolinao, Philippines) in the face of frequent natural catastrophes. Restor Ecol 18(3):285-299

Sharma S, Oremus M (2018) PRISMA and AMSTAR show systematic reviews on health literacy and cancer screening are of good quality. $\mathrm{J}$ Clin Epidemiol 99:123-131
Suh D, Pomeroy R (2020a) Projected economic impact of climate change on marine capture fisheries in the Philippines. Front Mar Sci 2:232

Suh D, Pomeroy R (2020b) Projected economic impact of climate change on marine capture fisheries in the Philippines. Front Mar Sci 7:14

Tanaka KR (2019) Chapter 19 - Integrating environmental information into stock assessment models for fisheries management. In: Cheung WWL, Ota Y (eds) Cisneros-Montemayor, A. M. Elsevier, Predicting Future Oceans, pp 193-206

Tran TC, Le S, Nguyen KA (2017) Vietnam's small and medium sized enterprises development: Characteristics, constraints and policy recommendations. In: Lim H (ed.), SME in Asia and Globalization, ERIA Research Project Report 2007-5:323-364

van Eck NJ, Waltman L (2010) Software survey: VOSviewer, a computer program for bibliometric mapping. Scientometrics 84(2):523-538

Wang Z, Zhao Y, Wang B (2018) A bibliometric analysis of climate change adaptation based on massive research literature data. $\mathrm{J}$ Clean Prod 199:1072-1082

Williams C (1996) Combatting marine pollution from land-based activities: Australian initiatives. Ocean Coast Manag 33(1-3):87-112

Yamaguchi H, Sai K (2015) Simulating the vertical dynamics of phosphate and their effects on the growth of harmful algae. Estuar Coast Shelf Sci 164:425-432

Yang ECL, Khoo-Lattimore C, Arcodia C (2017) A systematic literature review of risk and gender research in tourism. Tour Manag 58:89100

Yin R (2016) Qualitative research from start to finish. The Guilford Press, New York

Yñiguez AT, Lim PT, Leaw CP, Jipanin SJ, Iwataki M, Benico G, Azanza RV (2020) Over 30 years of HABs in the Philippines and Malaysia: what have we learned? Harmful Algae 102. https://doi. org/10.1016/j.hal.2020.101776

Publisher's note Springer Nature remains neutral with regard to jurisdictional claims in published maps and institutional affiliations. 